\title{
Selected Metal Concentrations in Some Medical Herbs from Localities Around Mount Bjelasica
}

\author{
Vlatko Kastratović, ${ }^{1, *}$ (B) Nada Blagojević, ${ }^{2}$ () Vesna Vukašinović-Pešić ${ }^{2}$
}

\footnotetext{
1 Faculty of Natural Sciences and Mathematics, University of Montenegro, G. Washington Street, P. O. Box 5455, 81000 Podgorica, Montenegro

2 Faculty of Metallurgy and Technology, University of Montenegro, G. Washington Street, P. O. Box 5455, 81000 Podgorica, Montenegro

* Corresponding author's e-mail address: vlatkok@ucg.ac.me
}

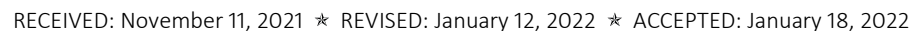

Abstract: The use of wild herbs to relieve and treat many human diseases is increasing worldwide, due to their medicinal features and limited side effects. The content of metals in them is of great interest. Our objective was to determine the levels of $\mathrm{Cu}, \mathrm{Fe}, \mathrm{Mn}, \mathrm{Ni}$, and $\mathrm{Zn}$ in individual parts of four medicinal plant species (Achillea millefolium L., Origanum vulgare L., Thymus serpyllum L., and Hypericum perforatum L.) and their native soil. For the study, we selected four sites located at the foot of Mount Bjelasica in Montenegro. Microwave-assisted digestion was applied for the dissolution of the samples and the metal concentrations were determined using atomic absorption spectrometry (AAS). All the investigated metals are most concentrated in the roots of the tested herbs. The translocation of metal from the root to the aboveground parts is different and depends on the metal and the plant. All the tested plants contain the most Fe (except oregano) and the least Ni. The most significant levels of $\mathrm{Zn}\left(44.6-116 \mathrm{mg} \mathrm{kg}^{-1}\right), \mathrm{Ni}\left(0.10-26.3 \mathrm{mg} \mathrm{kg}^{-1}\right)$ and $\mathrm{Mn}\left(28.4-329 \mathrm{mg} \mathrm{kg}^{-1}\right)$ were found in 0 . vulgare, the largest concentration of $\mathrm{Cu}\left(20.6-85.4 \mathrm{mg} \mathrm{kg}^{-1}\right)$ in $\mathrm{H}$. perforatum and $\mathrm{Fe}\left(108-1324 \mathrm{mg} \mathrm{kg}^{-1}\right)$ showed its largest value in T. serpyllum.

Keywords: Achillea millefolium, Origanum vulgare, Thymus serpyllum, Hypericum perforatum.

\section{INTRODUCTION}

$\mathbf{T}$ HE use of plants for therapeutic purposes has a long and continuous tradition among people on all continents. As natural medicines, they are considered safer for human health than synthetic ones, because medicinal herbs are not aggressive, have no serious side effects and are generally available at a low price. ${ }^{[1]}$ The World Health Organization (WHO) reported that $65-80 \%$ of the population of developing countries is dependent on medicinal plants as the only means of accessing basic health care. ${ }^{[2]}$

There is a widespread misconception that natural herbs and plants are inherently safe; nevertheless, there has been a large volume of reports on incidences of toxicity and adverse effects linked to the use of herbal plants and their formulations in different parts of the world. ${ }^{[3]}$

Plants are an important mechanism for the transition of trace elements from the soil into human beings. ${ }^{[4]}$ Several transition metals such as iron (Fe), manganese $(\mathrm{Mn})$, copper $(\mathrm{Cu})$, zinc $(\mathrm{Zn})$ and nickel $(\mathrm{Ni})$, and are needed by living organisms in minute quantities for various physiological and biochemical purposes. ${ }^{[5]}$ The presence of some transition metals beyond the permissible limits can cause metabolic disturbances. Thus, both a deficiency and an excess of essential micronutrients can be harmful to human health. ${ }^{[6]}$

Accordingly, quality control of medicinal plants is also important in terms of identifying the trace element content. ${ }^{[4]}$ It is important to emphasize that the best benefit to human health depends on obtaining the correct amount of the elements in the right form and at the right time. ${ }^{[7]}$

Higher amounts of metals entering the food chain could, eventually, be harmful to both humans and animals. ${ }^{[8]}$ Thus, a better understanding of the factors affecting the uptake and accumulation of metals in some species is especially important for the collection and cultivation of wild medicinal plants. ${ }^{[8]}$

The same plant species can differ in microelement content under different ecological conditions, while diverse species in the same biotope accumulate different amounts of microelements. ${ }^{[9]}$ 
Transition metal uptake by plants is a complex process, governed by numerous factors which are interlinked and which influence each other: plant species, genotype, the availability and mobility of the metals in the soil, and soil properties, such as: $\mathrm{pH}$, organic matter content, clay content, redox potential, and so on. ${ }^{[8,10-12]} \mathrm{A}$ knowledge of the influence of soil properties on the metal uptake could be very useful when the choice of the location from which to collect wild plants is made or suggest potential agricultural techniques for the plantation and cultivation of these plants. ${ }^{[8]}$

According to Yoon et al., ${ }^{[13]}$ wild plants should be preferred for phytoremediation since these plants are often better in terms of growth, development, reproduction and general survival under stress conditions as compared to plants introduced from other environments. [14]

Currently, there are many aromatic medicinal plants that are collected and consumed in Montenegro. Among these plants, yarrow (Achillea millefolium L.), oregano (Origanum vulgare L.), thyme (Thymus serpyllum L.), and St. John's wort (Hypericum perforatum L.) and are the most popular aromatic medicinal herbs used for medical purposes or to help maintain good health. Aromatic wild herbs have various applications in ethnopharmacology. In this context, it is important to ensure a good level of quality control to protect consumers from potential contamination. ${ }^{[15]}$ Considering the complexity of these aromatic medicinal herbs and their inherent biological variation, it thus becomes necessary to evaluate their safety, efficacy and quality. ${ }^{[2,16]}$

Thus far, there has been little emphasis on the metal content in wild plant products from Montenegro. ${ }^{[17]}$ In particular, no data on the concentration of metals in the individual parts of medicinal plants has so far been presented.

In this study, the content of five selected metals $(\mathrm{Cu}, \mathrm{Mn}, \mathrm{Ni}, \mathrm{Fe}$ and $\mathrm{Zn}$ ) in the soil and in the different organs of yarrow (Achillea millefolium L.), oregano (Origanum vulgare L.), thyme (Thymus serpyllum L.), and St. John's wort (Hypericum perforatum L.) were investigated, based on samples collected from sites around Mount Bjelasica. Mount Bjelasica occupies an area in the central-continental region of Montenegro, between $42^{\circ}$ and $43^{\circ}$ North in latitude and $19^{\circ}$ and $20^{\circ}$ East in longitude. The area of the Bjelasica mountain is characterized by extraordinary ecosystemic diversity, which makes it one of the important areas and centers of biological diversity on the Balkan Peninsula and beyond. ${ }^{[18]}$

The determination of the metal content in soil; the estimation of their bioavailability; the analysis of the relevant ratios of metal content in the soil and herbs; and the nature of the distribution in different plant tissues, may all indicate possible pathways of absorption, distribution, and highlight the potential for bioaccumulation.

\section{EXPERIMENTAL SECTION}

\section{Plant Collection}

The plants used in this study were collected by hand during the flowering and fruiting stages from the southern slopes of Mount Bjelasica in Montenegro, from four separate locations, at the beginning of August 2020. The raw materials from the following species of plants were studied: yarrow (Achillea millefolium L.), oregano (Origanum vulgare $\mathrm{L}$.), thyme (Thymus serpyllum L.), and St. John's wort (Hypericum perforatum L.).

At each location of about $2000 \mathrm{~m}^{2}, 7-8$ whole healthy plants of a similar size, shape and weight were sampled manually in order to repeat the results for each site. The plant material was labeled, packed in polyethylene bags and transferred to the laboratory in the shortest possible time. Soil samples were also taken from the same locations as plants to a depth of $0-20 \mathrm{~cm}$. Stones and coarse plant material were mechanically removed. The soil samples were placed in plastic boxes, carefully labelled and transferred to the laboratory for further analysis. The selected locations were at least $5 \mathrm{~km}$ away from the main roads and larger settlements, as well as a minimum distance of $100 \mathrm{~m}$ from smaller roads and houses.

\section{Sample Preparation}

The identification of the plants was made by Department of Biology, Faculty of Natural Sciences and Mathematics of Montenegro. The sampled plant material was first washed with tap water, and then twice with deionized water and gently dried with a paper towel. The samples plants were separated into root, stem, leaf and flower to determine bioaccumulation diversity of the plant organs. The plant material was then air dried. The samples were ground into a fine powder and homogenized in an electrical mill (BüchiMixer B-400). The samples were mineralized to avoid the influence of the matrix. ${ }^{[19]}$ An amount of $0.5 \mathrm{~g}$ of prepared samples were approximately measured with an accuracy of $\pm 0.0001 \mathrm{~g}$ and mineralized using a Milestone Microwave Ethos model 1600 , with a mixture of $65 \%(w / w) \mathrm{HNO}_{3}$ and $30 \%(w / w) \mathrm{H}_{2} \mathrm{O}_{2}(3: 1 \mathrm{v} / v) .{ }^{[20]}$ Mineralization was realized in two stages: pre-treatment at a power of $300 \mathrm{~W}$ for a period of six min, followed by five minutes of microwave digestion at a power of $500 \mathrm{~W}$. After digestion, the solutions were diluted with deionized water to a final volume of $50.0 \mathrm{~cm}^{3}$.

The sediment samples were dried in air and then in an oven at $75^{\circ} \mathrm{C}$ for 48 hours using SLW 53, 56L POL EKO Aparatura $\left.{ }^{\mathrm{TM}}\right) .{ }^{[19]}$ The dried sediment samples were ground in an agate mortar and sieved through a $1.5 \mathrm{~mm}$ sieve (a FASIL AD Arilje). Approximately, $0.5 \mathrm{~g}( \pm 0.0001 \mathrm{~g})$ of each sample was mineralized under pressure and high 
temperature and microwave digested with a mixture of $37 \%(w / w) \mathrm{HCl}: 65 \%(w / w) \mathrm{HNO}_{3}(3: 1 v / v) .{ }^{[19-20]}$ After digestion, the solutions were diluted using $2 \mathrm{M} \mathrm{HNO}_{3}$ to a final volume of $100 \mathrm{~cm}^{3}{ }^{[20-21]}$

In order to determine the amount of mobile and bioavailable amounts of metals, extraction with $0.1 \mathrm{M}$ EDTA was performed. In this way, the real conditions prevailing in the environment are simulated. The soil/0.1 M EDTA mixture $(1 \mathrm{~g}: 50 \mathrm{~mL}$ ) was stirred for $1 \mathrm{~h}$ on a magnetic stirrer and filtered.

\section{Determination of Metal Content}

All the parts of the plant samples and soils were prepared in triplicate and their average value was assessed. Blank solutions were added to the series of samples and measured after every tenth sample determination. The concentrations of the metals $(\mathrm{Cu}, \mathrm{Mn}, \mathrm{Ni}, \mathrm{Fe}$ and $\mathrm{Zn}$ ) were determined by the AAS technique using a atomic absorption spectrometer (PinAAcle 900, Perkin Elmer). Basic standard solutions of $\mathrm{Cu}, \mathrm{Fe}, \mathrm{Mn}, \mathrm{Ni}$ and $\mathrm{Zn}$ concentrations of $1000 \mathrm{mg} \mathrm{kg}^{-1}$ were made from Merck chemicals. The standard solutions were diluted with deionized water to bring the element concentrations to a suitable concentration range. The operating conditions of the instrument during determination are given in Table 1.

The accuracy and precision of the method were evaluated using the certified reference material, in this case NCS ZC73014 Tea leaves (National Institute of Standards and Technology, NIST, Gaithersburg, MD, USA) and the relevant standard for trace elements in the soil (SRM 2709). The recovery of measured values for the selected elements lay within $\pm 8 \%$ of the certified values.

\section{Statistical Analysis}

The Microsoft Excel 2000 package was used for the calculation of the mean and standard deviation. A one-way ANOVA at a value of $p<0.05$ was performed between the content of each metal in the roots, stems, leaves and flowers and between the content of each metal in the tested plants. If the differences between the mean values were significant at the $5 \%$ level, a post hoc Duncan test was used to determine the minimum allowable differences between particular result groups. All the calculations were performed using the SPSS (version 11.5) software package (SPSS Inc., Chicago, USA).

The ability of plants to absorb and accumulate metals from the growth media was evaluated using the bioconcentration factor (BCF). ${ }^{[22]}$ The BCF value was calculated as the ratio of the concentrations of metals in the plants and sediments:

$$
\mathrm{BCF}=[\text { Metal }]_{\text {part of plant }} /[\text { Metal }]_{\text {soil }}
$$

The possibility of plants to transport metals from the roots to the above-ground organs was estimated using the translocation ability (TA). The value of the translocation ability was calculated as the ratio of the concentrations of metals in roots and a given part of the plant:

$$
\mathrm{TA}=[\text { Metal }]_{\text {root }} /[\text { Metal }]_{\text {part of the plant }} \text {. }
$$

\section{RESULTS AND DISCUSSION}

In Table 2 content tested metals of the soil from which the plant samples were taken are provided. Table 2 also contains bioavailable metal contents based on EDTA extraction.

\begin{tabular}{|c|c|c|c|c|c|c|c|}
\hline Metal & Wavelenght / nm & Slit / nm & Relative noise & Flame Gases & $\begin{array}{c}\text { Char. Conc. } \\
\text { Check / mg L-1 }\end{array}$ & $\begin{array}{c}\text { Linear Range / } \\
\mathrm{mg} \mathrm{L}^{-1}\end{array}$ & $\begin{array}{c}\text { Lamp current / } \\
\mathrm{mA}\end{array}$ \\
\hline $\mathrm{Cu}$ & 324.8 & 0.7 & 1.0 & air-acetylene & 4.0 & 5.0 & 25 \\
\hline $\mathrm{Fe}$ & 248.3 & 0.2 & 1.0 & air-acetylene & 6.0 & 6.0 & 40 \\
\hline $\mathrm{Mn}$ & 279.5 & 0.2 & 1.0 & air-acetylene & 2.5 & 2.0 & 25 \\
\hline $\mathrm{Ni}$ & 232.0 & 0.2 & 1.0 & air-acetylene & 7.0 & 2.0 & 40 \\
\hline $\mathrm{Zn}$ & 213.9 & 0.7 & 1.0 & air-acetylene & 1.0 & 1.0 & 25 \\
\hline
\end{tabular}

Table 1. AAS operating conditions during the experiment

\begin{tabular}{|c|c|c|c|c|c|}
\hline \multicolumn{6}{|c|}{ Metal content in soil / mg kg-1 } \\
\hline & $\mathrm{Cu}$ & $\mathrm{Fe}$ & $\mathrm{Mn}$ & $\mathrm{Ni}$ & $\mathrm{Zn}$ \\
\hline $\min -\max$ & $61.0-88.1$ & $2360-2478$ & $607-1019$ & $57.4-104$ & $171-206$ \\
\hline average \pm SD & $70.4 \pm 14.7$ & $2419 \pm 48$ & $817 \pm 168$ & $74.3 \pm 20.8$ & $186 \pm 15$ \\
\hline \multicolumn{6}{|c|}{ Metals extracted with EDTA / mg kg-1 } \\
\hline & $\mathrm{Cu}$ & $\mathrm{Fe}$ & $\mathrm{Mn}$ & $\mathrm{Ni}$ & $\mathrm{Zn}$ \\
\hline $\min -\max$ & $24.7-30.1$ & $214-594$ & $203-396$ & $6.48-10.2$ & $3.73-20.2$ \\
\hline average \pm SD & $27.7 \pm 2.72$ & $423 \pm 158$ & $274 \pm 87.5$ & $8.34 \pm 1.99$ & $10.5 \pm 7.41$ \\
\hline
\end{tabular}

Table 2. Content of tested metals in soil and their bioavailability

DOI: $10.5562 /$ cca3855 
Table 3. Metal concentrations ( $\mathrm{mg} \mathrm{kg}^{-1} \mathrm{dw}$ ) in parts of the investigated medical plants; minimum and maximum concentrations and average concentrations \pm standard deviation

\begin{tabular}{|c|c|c|c|c|c|}
\hline \multirow{2}{*}{ Metal } & & \multicolumn{4}{|c|}{$\begin{array}{l}\text { min.-max. } / \mathrm{mg} \mathrm{kg}^{-1} \\
\text { Average } \pm \text { S.D. }\end{array}$} \\
\hline & & Achillea millefolium & Origanum vulgare & Thymus serpyllum & Hypericum perforatum \\
\hline \multirow{4}{*}{$\mathrm{Cu}$} & root & $\begin{array}{c}29.2-34.5 \\
31.1 \pm 2.37 a^{*}(b)^{* *}\end{array}$ & $\begin{array}{c}49.4-57.3 \\
52.1 \pm 3.52 \mathrm{a}(\mathrm{b})\end{array}$ & $\begin{array}{c}26.1-35.3 \\
30.7 \pm 4.29 \mathrm{a}(\mathrm{b})\end{array}$ & $\begin{array}{c}78.8-88.4 \\
85.4 \pm 4.46 \text { a (a) }\end{array}$ \\
\hline & stem & $\begin{array}{c}25.6-33.4 \\
28.5 \pm 3.46 \text { a (a) }\end{array}$ & $\begin{array}{c}22.5-28.6 \\
24.9 \pm 2.64 b(a)\end{array}$ & $\begin{array}{c}22.8-29.4 \\
26.3 \pm 2.83 \mathrm{a}(\mathrm{a})\end{array}$ & $\begin{array}{c}27.4-32.0 \\
28.9 \pm 2.09 \mathrm{~b}(\mathrm{a})\end{array}$ \\
\hline & leaf & $\begin{array}{c}29.6-34.8 \\
32.7 \pm 2.23 \text { a (a) }\end{array}$ & $\begin{array}{c}28.5-35.4 \\
30.6 \pm 3.21 \mathrm{ab}(\mathrm{a})\end{array}$ & $\begin{array}{c}12.4-19.3 \\
16.9 \pm 3.13 \mathrm{a}(\mathrm{a})\end{array}$ & $\begin{array}{c}18.1-23.3 \\
20.6 \pm 2.39 b(a)\end{array}$ \\
\hline & flower & $\begin{array}{c}37.2-41.9 \\
39.2 \pm 1.98 \text { a (a) }\end{array}$ & $\begin{array}{c}35.5-43.1 \\
40.3 \pm 3.34 \mathrm{ab}(\mathrm{a})\end{array}$ & $\begin{array}{c}20.3-25.5 \\
23.2 \pm 2.21 \mathrm{a} \mathrm{(a)}\end{array}$ & $\begin{array}{c}23.1-29.3 \\
25.9 \pm 3.04 \text { b (a) }\end{array}$ \\
\hline \multirow{4}{*}{$\mathrm{Fe}$} & root & $\begin{array}{c}986-1158 \\
1094 \pm 77 \text { a (a) }\end{array}$ & $\begin{array}{c}1321-1476 \\
1385 \pm 73 \text { a (a) }\end{array}$ & $\begin{array}{c}1291-1382 \\
1324 \pm 41 a(b)\end{array}$ & $\begin{array}{c}60.7-67.9 \\
63.1 \pm 3.23 \mathrm{a}(\mathrm{b})\end{array}$ \\
\hline & stem & $\begin{array}{c}289-352 \\
327 \pm 28 b(a b)\end{array}$ & $\begin{array}{c}114-174 \\
141 \pm 27 b(b)\end{array}$ & $\begin{array}{c}912-1007 \\
956 \pm 41 \mathrm{a}(\mathrm{a})\end{array}$ & $\begin{array}{c}32.5-35.2 \\
33.6 \pm 1.29 \mathrm{a}(\mathrm{b})\end{array}$ \\
\hline & leaf & $\begin{array}{c}207-246 \\
229 \pm 16 b \text { (a) }\end{array}$ & $\begin{array}{c}195-223 \\
206 \pm 12 b(a)\end{array}$ & $\begin{array}{c}241-285 \\
262 \pm 20 \text { b (a) }\end{array}$ & $\begin{array}{c}46.6-51.8 \\
49.7 \pm 2.27 \mathrm{a}(\mathrm{a})\end{array}$ \\
\hline & flower & nd & $\begin{array}{c}27.4-36.7 \\
33.5 \pm 4.21 \mathrm{~b}(\mathrm{a})\end{array}$ & $\begin{array}{c}96-128 \\
108 \pm 14 b(a)\end{array}$ & $\begin{array}{c}48.1-53.6 \\
50.1 \pm 2.42 \mathrm{a}(\mathrm{a})\end{array}$ \\
\hline \multirow{4}{*}{$\mathrm{Mn}$} & root & $\begin{array}{c}128-155 \\
140 \pm 11.1 \mathrm{a}(\mathrm{b})\end{array}$ & $\begin{array}{c}293-354 \\
329 \pm 26 \text { a (a) }\end{array}$ & $\begin{array}{c}169-207 \\
185 \pm 17 a(b)\end{array}$ & $\begin{array}{c}77.6-89.1 \\
85.4 \pm 5.25 \mathrm{a}(\mathrm{b})\end{array}$ \\
\hline & stem & $\begin{array}{c}34.9-42.6 \\
37.9 \pm 3.56 \text { a (a) }\end{array}$ & $\begin{array}{c}26.1-31.6 \\
28.4 \pm 2.33 \mathrm{~b} \text { (a) }\end{array}$ & $\begin{array}{c}84.6-93.1 \\
87.6 \pm 3.87 \text { a (a) }\end{array}$ & $\begin{array}{c}33.4-39.1 \\
36.8 \pm 2.61 \mathrm{a} \text { (a) }\end{array}$ \\
\hline & leaf & $\begin{array}{c}64.8-73,2 \\
69.3 \pm 3.67 \text { a (a) }\end{array}$ & $\begin{array}{c}46.1-50,3 \\
48.2 \pm 1.74 \text { b (a) }\end{array}$ & $\begin{array}{c}79.2-88.4 \\
82.6 \pm 4.08 \text { a (a) }\end{array}$ & $\begin{array}{c}119-144 \\
134 \pm 11 \mathrm{a}(\mathrm{a})\end{array}$ \\
\hline & flower & $\begin{array}{c}27.3-33.5 \\
30.2 \pm 2.95 \text { a (a) }\end{array}$ & $\begin{array}{c}33.6-42.3 \\
38.4 \pm 3.60 \mathrm{~b}(\mathrm{a})\end{array}$ & $\begin{array}{c}58.0-63.2 \\
60.1 \pm 2.30 \text { a (a) }\end{array}$ & $\begin{array}{c}61.3-67.7 \\
64.3 \pm 3.14 \text { a (a) }\end{array}$ \\
\hline \multirow{4}{*}{$\mathrm{Ni}$} & root & $\begin{array}{c}2.12-3.07 \\
2.52 \pm 0.40 a(b)\end{array}$ & $\begin{array}{c}23.2-31.2 \\
26.3 \pm 3.49 \text { a (a) }\end{array}$ & $\begin{array}{c}5.15-5.52 \\
5.31 \pm 0.17 \mathrm{a}(\mathrm{b})\end{array}$ & $\begin{array}{c}3.24-3.61 \\
3.45 \pm 0.16 \mathrm{a}(\mathrm{b})\end{array}$ \\
\hline & stem & $\begin{array}{c}1.61-2.05 \\
1.83 \pm 0.16 \mathrm{a}(\mathrm{a})\end{array}$ & $\begin{array}{c}1.52-1.97 \\
1.77 \pm 0.20 \mathrm{~b}(\mathrm{a})\end{array}$ & $\begin{array}{c}2.06-2.97 \\
2.54 \pm 0.43 \mathrm{a}(\mathrm{a})\end{array}$ & $\begin{array}{c}0.65-0.90 \\
0.75 \pm 0.12 \mathrm{a}(\mathrm{a})\end{array}$ \\
\hline & leaf & $\begin{array}{c}0.77-1.24 \\
0.94 \pm 0.21 \mathrm{a}(\mathrm{a})\end{array}$ & $\begin{array}{c}0.07-0.12 \\
0.10 \pm 0.03 b(a)\end{array}$ & $\begin{array}{c}0.32-0.69 \\
0.54 \pm 0.16 \text { a (a) }\end{array}$ & $\begin{array}{c}0.16-0.24 \\
0.19 \pm 0.03 a \text { (a) }\end{array}$ \\
\hline & flower & $\begin{array}{c}0.91-1.23 \\
1.04 \pm 0.14 \mathrm{a} \text { (a) }\end{array}$ & $\begin{array}{c}2.19-2,63 \\
2.42 \pm 0.24 b(a)\end{array}$ & $\begin{array}{c}1.88-2.34 \\
2.18 \pm 0.20 \mathrm{a} \text { (a) }\end{array}$ & $\begin{array}{c}0.70-0.96 \\
0.87 \pm 0.11 \mathrm{a}(\mathrm{a})\end{array}$ \\
\hline \multirow{4}{*}{$\mathrm{Zn}$} & root & $\begin{array}{c}32.8-40.1 \\
35.8 \pm 3.13 \mathrm{a}(\mathrm{b})\end{array}$ & $\begin{array}{c}101-127 \\
116 \pm 12 \text { a (a) }\end{array}$ & $\begin{array}{c}43.3-49.3 \\
46.9 \pm 2.61 \mathrm{a}(\mathrm{b})\end{array}$ & $\begin{array}{c}54.1-63.6 \\
57.2 \pm 4.37 \mathrm{a}(\mathrm{b})\end{array}$ \\
\hline & stem & $\begin{array}{c}15.5-20.8 \\
18.5 \pm 2.21 \mathrm{a}(\mathrm{a})\end{array}$ & $\begin{array}{c}39.4-47.8 \\
44.6 \pm 3.75 \text { c (a) }\end{array}$ & $\begin{array}{c}40.3-48.4 \\
42.7 \pm 3.83 \text { a (a) }\end{array}$ & $\begin{array}{c}20.5-25.1 \\
22.2 \pm 2.01 b(a)\end{array}$ \\
\hline & leaf & $\begin{array}{c}26.1-34.2 \\
29.5 \pm 3.44 \text { a (c) }\end{array}$ & $\begin{array}{c}71.4-79.8 \\
77.3 \pm 3.98 \text { b (a) }\end{array}$ & $\begin{array}{c}39.7-46.8 \\
42.3 \pm 3.11 \mathrm{a}(\mathrm{bc})\end{array}$ & $\begin{array}{c}65.4-72.1 \\
69.8 \pm 2.99 a(a b)\end{array}$ \\
\hline & flower & $\begin{array}{c}25.1-31.6 \\
27.3 \pm 3.02 a(b)\end{array}$ & $\begin{array}{c}50.2-63.2 \\
57.6 \pm 6.04 \mathrm{bc}(\mathrm{a})\end{array}$ & $\begin{array}{c}33.1-37.7 \\
36.2 \pm 2.10 a(a b)\end{array}$ & $\begin{array}{c}49.2-54.7 \\
51.1 \pm 2.45 \text { ab (ab) }\end{array}$ \\
\hline
\end{tabular}

* The values of individual metals with the same first letter(s) are not significantly different at $p=0.05$ in the column (i.e. between different parts of the plant ** The values in individual parts of the plant with the same letter(s) in parentheses are not significantly different at $p=0.05$ in the row (i.e. between plants)

The concentrations of the studied metals $\left(\mathrm{mg} \mathrm{kg}^{-1}\right)$ in the tested soils are as follows, in descending order: Fe (2419) $>\mathrm{Mn}(817)>\mathrm{Zn}(186)>\mathrm{Ni}(74.3)>\mathrm{Cu}(70.4)$.

Extraction with EDTA releases metals from the soil that are bound to organic complexes. ${ }^{[12,23]}$ Metals associated with the carbonates and hydroxides of Fe and $\mathrm{Mn}$ are also extracted.[24] In the exchangeable, easily soluble fraction, the highest amounts comparing to the total content were shown for $\mathrm{Cu}(39.3 \%)$ and $\mathrm{Mn}$ (33.5\%), followed by Fe (17.5\%) and $\mathrm{Ni}(11.2 \%)$ and the lowest level was seen for $\mathrm{Zn}(5.65 \%)$.

Table 3 shows the minimum and maximum concentrations of the tested metals in some parts ( $\mathrm{mg} \mathrm{kg}^{-1}$ dry matter) of the investigated herbs, as well as the average concentration \pm the standard deviation; the values in individual parts of the plant with the same letter(s) in parentheses are not significantly different at $p=0.05$ in their row (i.e. between the plants). 
All the investigated metals were most concentrated in the roots of the plants. The translocation of metal from the root to the aboveground parts is different and depends on the metal and the plant. All the tested plants showed Fe content to the greatest degree (except for oregano), while the least common element was $\mathrm{Ni}$. The most significant contest of $\mathrm{Zn}, \mathrm{Ni}$ and $\mathrm{Mn}$ was found in oregano, while St. John's wort showed the most $\mathrm{Cu}$ and Fe was most extensively present in thyme.

The bioaccumulation ability of the tested medical plants is expressed through the bioaccumulation factor, most notably the BCF (root/soil) and the BCF (flower/soil), as presented in Figure 1. The greatest degree of bioaccumulation of the examined metals, from soil to root, was shown by oregano, except for the case St. John's wort for the bioaccumulation of $\mathrm{Cu}$. The lowest levels of bioaccumulation for $\mathrm{Cu}, \mathrm{Zn}$ and $\mathrm{Ni}$ were shown by yarrow, while the least bioaccumulation of Fe and Mn was recorded in St. John's wort.

Observing all the herbs tested collectively, the highest accumulation capacity was recorded for $\mathrm{Cu}$ and the lowest for $\mathrm{Ni}$.

The values of the metal translocation ability of the tested herbs are given in Table 4. The translocation between the different parts of the herbs depended on the type of metal and the type of plants. ${ }^{[25]}$ From the root to the above-ground organs, the most mobile metals were $\mathrm{Zn}$ and $\mathrm{Cu}$, while $\mathrm{Mn}, \mathrm{Ni}$ and $\mathrm{Cu}$ showed the lowest levels of mobility. The most significant mobility among the investigated metals was shown through the tissue of $A$. millefolium and the lowest through the tissue of $O$. vulgare. $T$. serpyllum and $H$. perforatum have a similar level of metal translocation through their tissues.

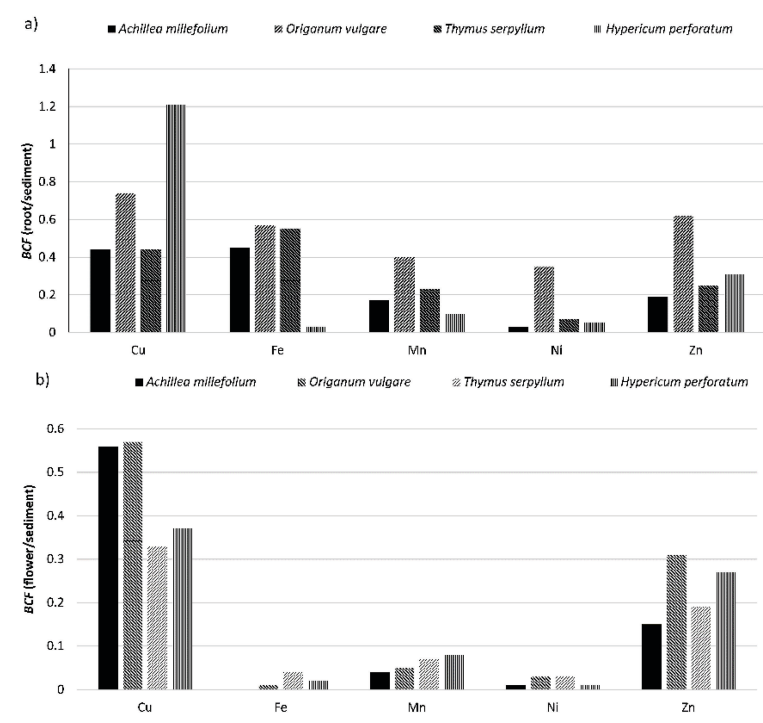

Figure 1. Seasonal changes in the bioconcentration factor (BCF): a) the root and $b$ ) the flower.

\section{Achillea millefolium (yarrow)}

The content of $\mathrm{Ni}, \mathrm{Zn}$ and $\mathrm{Mn}$ in the yarrow was lower or in the range of the normal value for these elements in plants. ${ }^{[26-28]}$ The content of both $\mathrm{Cu}$ and Fe are above normal levels for plants.

The sequence of metals in the tissues of $A$. millefolium is not the same as the order they are found in the soil (Tables II and III). This could be explained by the stronger influence of the genetic characteristics of the studied medicinal plant species, as well as certain soil factors, which often have opposite effects on the intake of metals. ${ }^{[8]}$

In other works ${ }^{[1,29-30]} \mathrm{Zn}$ content has been shown to be higher in the tissues of $A$. millefolium than the $\mathrm{Cu}$ content in the same material. The physiological activities of the medicinal plant influence $\mathrm{Zn}$ absorption and the interactions with many elements such as $\mathrm{Fe}$ and $\mathrm{Cu}$. ${ }^{[29]}$

In several papers ${ }^{[1,8,14,30-31]}$ a lower content of $\mathrm{Cu}$ and $\mathrm{Fe}$ was recorded in the tissues of $A$. millefolium than in our work. The zinc content in our $A$. millefolium samples was lower than in the samples from other regions. . $^{[8,30,33-34]}$ Nickel and $\mathrm{Mn}$ content were lower in some reports ${ }^{[14,29,34]}$ and higher in some other papers ${ }^{[1,8,30]}$ when compared to our results.

\section{Origanum vulgare (oregano)}

$O$. vulgare contains the highest amounts of $\mathrm{Zn}$ and $\mathrm{Ni}$ of all the tested plants. This plant present in the spontaneous Montenegrin flora may well be an important source of $\mathrm{Zn}$ and $\mathrm{Ni}$ for animal nutrition and, therefore, their use in future mineral nutrition studies may be justified.

The content of $\mathrm{Cu}$ and $\mathrm{Fe}$ in the root is above normal levels for plants. ${ }^{[26-28]}$ The contents of $\mathrm{Zn}, \mathrm{Ni}$ and $\mathrm{Mn}$ are within the range of values common to plants.

The translocation from the root to the leaf and the flower is greatest for $\mathrm{Cu}$ and $\mathrm{Zn}$ and lowest for Ni. Metal concentrations in certain parts of the plant can reach the accumulation of roots from the soil, translocation through certain parts of the plant and by the deposition of particles from the air (in the case of the leaf and the flower). ${ }^{[29]}$

In the literature, we found no data on the content of metal in individual parts of Origanum vulgare. The data on the metal content in the whole plant or only in the aboveground parts from other regions are generally of the same order of magnitude as our results. Samples of oregano from the North Western Himalayas, ${ }^{[35]}$ southeast Serbia, ${ }^{[36]}$ the western part of Turkey, ${ }^{[37]}$ Romania $^{[38]}$ and samples purchased at local markets in Dubai ${ }^{[3]}$ all differ slightly (sometimes being larger and sometimes smaller) when compared to the content of test metals in the samples of oregano picked in Bjelasica, Montenegro. 
Table 4. The translocation ability (TA) of the examined herbs for metals

\begin{tabular}{|c|c|c|c|c|c|}
\hline Metal & & Achillea millefolium & Origanum vulgare & Thymus serpyllum & Hypericum perforatum \\
\hline \multirow{4}{*}{$\mathrm{Cu}$} & root/stem & 1.09 & 2.09 & 1.17 & 2.96 \\
\hline & root/leaf & 0.95 & 1.70 & 1.82 & 4.14 \\
\hline & stem/leaf & 0.87 & 0.81 & 1.56 & 1.40 \\
\hline & root/flower & 0.79 & 1.29 & 1.32 & 3.30 \\
\hline \multirow{4}{*}{$\mathrm{Fe}$} & root/stem & 3.34 & 9.82 & 1.38 & 1.88 \\
\hline & root/leaf & 4.78 & 6.72 & 5.05 & 1.27 \\
\hline & stem/leaf & 1.43 & 0.68 & 3.66 & 0.68 \\
\hline & root/flower & - & 41.3 & 12.2 & 1.26 \\
\hline \multirow{4}{*}{$\mathrm{Mn}$} & root/stem & 3.69 & 11.6 & 2.11 & 2.32 \\
\hline & root/leaf & 2.02 & 6.82 & 2.24 & 0.64 \\
\hline & stem/leaf & 0.55 & 0.59 & 1.06 & 0.28 \\
\hline & root/flower & 4.64 & 8.57 & 3.08 & 1.33 \\
\hline \multirow{4}{*}{$\mathrm{Ni}$} & root/stem & 1.38 & 14.8 & 2.09 & 4.60 \\
\hline & root/leaf & 2.68 & 263 & 9.83 & 18.2 \\
\hline & stem/leaf & 1.94 & 17.8 & 4.70 & 3.96 \\
\hline & root/flower & 2.43 & 10.9 & 2.44 & 3.96 \\
\hline \multirow{4}{*}{$\mathrm{Zn}$} & root/stem & 1.93 & 2.60 & 1.10 & 2.58 \\
\hline & root/leaf & 1.21 & 1.50 & 1.11 & 0.82 \\
\hline & stem/leaf & 0.63 & 0.58 & 1.01 & 0.32 \\
\hline & root/flower & 1.31 & 2.01 & 1.30 & 1.12 \\
\hline
\end{tabular}

\section{Thymus serpyllum (thyme)}

The contents of $\mathrm{Cu}$ (except in the leaves) and Fe (except in the flowers) are higher than the normal content levels of these metals in plants. ${ }^{[26-28]}$ The content levels of the other investigated metals are in the range of values common to plants.

In the tested metals, the same order of contents was not recorded in relation to the individual parts of $A$. millefolium. It is probable that the distribution of metals to the various parts of the plant depends on the properties of the metal, its ionic diameter and the translocation ability of the plant. The distribution of $\mathrm{Zn}, \mathrm{Fe}$ and $\mathrm{Mn}$ by the parts of $T$. serpyllum follows a declining trend: root $>$ stem $>$ leaf $>$ flower, while $\mathrm{Cu}$ and $\mathrm{Ni}$ are more commonly found in the leaf than in the flower. In the work by Musielińska et al., [33] the distribution of $\mathrm{Zn}$ in the parts of $T$. serpyllum followed the reverse trend: leaf $>$ flower $>$ stem $>$ root. In the same paper, the lead content was highest in the root while it was smaller and more uniform in the stem, leaf, and flower.

In the samples of $T$. serpyllum from the Ash-Shoubak region in the west of Jordan ${ }^{[15]}$ a lower metal content was recorded compared to our samples. Compared to the T. serpyllum samples from Serbia (Vojvodina), ${ }^{[1]}$ our samples contain a higher concentration of $\mathrm{Cu}$ and a lower concentration of $\mathrm{Mn}$, while the content levels of $\mathrm{Fe}, \mathrm{Zn}$ and $\mathrm{Ni}$ are similar.

\section{Hypericum perforatum (St. John's wort)}

The greater $\mathrm{Zn}$ and $\mathrm{Mn}$ content in the flower and leaf compared to the root and stem is probably due to the deposition of these metals from the air and not simply the translocation from the root. The distribution of metals in some parts of the plant is the result of differences in the amount and rate of metal input, primarily by root pressure and their release into the environment, notably through the transpiration of the leaves. ${ }^{[39-40]}$ Some metals are accumulated in the roots, probably because of certain physiological barriers to the transport of toxic elements in trace amounts. Those metals essential to metabolic needs are easily transported to the above-ground parts of the plant. ${ }^{[22]}$

Compared to $H$. perforatum samples from other regions, the $\mathrm{Cu}$ content in our samples is generally higher, while both $\mathrm{Zn}$ and $\mathrm{Mn}$ are either in a similar range to other results or higher than in other samples. The contents of both $\mathrm{Fe}$ and $\mathrm{Ni}$ in our samples of $\mathrm{H}$. perforatum are in a similar range or lower when compared to samples from other regions. ${ }^{[1,8,29,30,34,36,41-43]}$ The reason for this relationship between the content of the metals tested in the $H$. perforatum tissues in comparison to samples from other regions is probably due to the increased mobility of $\mathrm{Cu}$ in the soil samples. 


\section{CONCLUSIONS}

The species of plants tested (thyme, yarrow, St. John's wort and oregano), which all have potential uses for human health, all show different concentrations of metals depending on the part and species of tested plant.

The most significant bioaccumulation ability in terms of the measured metals, from the soil to the root, was shown by Origanum vulgare, except for the bioaccumulation of $\mathrm{Cu}$, for which the greatest value was shown by Hypericum perforatum. The lowest bioaccumulation rates for $\mathrm{Cu}, \mathrm{Zn}$ and Ni were shown by Achillea millefolium, while the least significant bioaccumulation of $\mathrm{Fe}$ and $\mathrm{Mn}$ was recorded in Hypericum perforatum.

The greatest mobility investigated metals was showed through the tissue of $A$. millefolium and the least through the tissue of $O$. vulgare.

In the tested herbal material $\mathrm{Zn}, \mathrm{Ni}, \mathrm{Mn}$ and, to some extent, $\mathrm{Cu}$ and $\mathrm{Fe}$ are within the limits that are common to general plant content levels. Based on the results of this study, it is recommended that the tested herbs can be used for daily consumption without any negative consequences for human health insofar as the content of investigated metals is concerned.

\section{REFERENCES}

[1] Ž. Mihaljev, M. Živkov-Baloš, ž. Ćupić, S. Jakšić, Acta. Pol. Pharm. 2014, 71(3), 385-391.

[2] World Health Organization (WHO), Traditional Medicine \& Growing Needs and Potential, WHO Policy Perspective on Medicines, 2016.

http://apps.who.int/medicinedocs/en/d/Js2293e/, accessed in June 2016

[3] R. Dghaim, S. A. Khatib, H. Rasool, M. A. Khan, J. Environ. Public. Health, 2015, 4, 1-6. https://doi.org/10.1155/2015/973878

[4] I. Yener, Journal of the Institute of Science and Technology, 2019, 9(3), 1492-1502. https://doi.org/10.21597/jist.517739

[5] H. F. Farrag, Y. M. Al-Sodany, F. G. Otiby, World Appl. Sci. J. 2013, 28(5), 644-653.

https://doi.org/10.5829/idosi.wasj.2013.28.05.2018

[6] V. K. Jena, S. Gupta, K. S. Patel, S. C. Patel, J. Mater. Environ. Sci. 2013, 4(3), 384-389.

https://www.jmaterenvironsci.com/Document/vol 4/vol4_N3/48-JMES335-2012-Jena.pdf

[7] A. Ghani, S. Saeed, Z. Ali, I. Ahmad, M. Ishtiaq, Afr. J. Biotechnol. 2012, 11(76), 14064-14068.

https://doi.org/10.5897/AJB12.757

[8] D. Radanović, S. Antić-Mladenović, M. Jakovljević, Acta Hortic. 2002, 576, 295-301. https://doi.org/10.17660/ActaHortic.2002.576.44
[9] V. K. Kashin, Chem. Sustain. Dev. 2011, 19, 237-244.

[10] B. J. Alloway, Heavy Metals in Soils, Springer, Dordrecht, 2013.

https://doi.org/10.1007/978-94-007-4470-7

[11] H. Marschner, Mineral nutrition of higher plants $2^{\text {nd }}$ edition. Academic Press, Great Britain, 1995.

[12] A. Kabata-Pendias, H. Pendias, Trace Elements in Soils and Plants, $3^{\text {rd }}$ ed., CRC Press, Boca Raton, London, New York, Washington, D.C., 2001. https://doi.org/10.1201/9781420039900

[13] J. X. Yoon, X. Cao, Q. Zhou, L.Q. Ma, Sci. Total. Environ. 2006, 368, 456-464.

https://doi.org/10.1016/j.scitotenv.2006.01.016

[14] S. Murtić, J. Jurković, E. Bašić, E. Hekić, Agron. Res. 2019, 17(1), 234-244.

http://dx.doi.org/10.15159/ar.19.005

[15] M. S. Abu-Darwish, Adv. Environ. Biol. 2009, 3(3), 296-301.

https://link.gale.com/apps/doc/A235281181/AONE?u= anon eed05c00\&sid=bookmark-AONE\&xid=09a9a71b

[16] World Health Organization, WHO, Guidelines for the Assessment of Herbal Medicines, Munich, Geneva, 1991. https://apps.who.int/iris/handle/10665/58865

[17] N. Blagojević, B. Damjanović-Vratnica, V. VukašinovićPešić, D. Đurović, Pol. J. Environ. Stud. 2009, 18(2), 167-173.

[18] Ministry of Spatial Planning and Environmental Protection of Montenegro, (2010). Prostorni plan posebne namjene NP "Bjelasica - Komovi" Rzup Ecosign - Horwat HTL.

http://www.mans.co.me/wp-content/uploads/or/ drzavnaPD/Bjelasica_Komovi/Tekst.pdf

[19] V. Kastratović, Ž. Jaćimović, M. Bigović, M. Kosović, D. Đurović, S. Krivokapić, Fresenius. Environ. Bull. 2017, 26(2),1247-1253.

[20] USEPA Method 3051A, Microwave assisted acid digestion of sediments, sludges, soils and oils, Revision 1, Washington, 2007.

https://www.epa.gov/esam/us-epa-method-3051amicrowave-assisted-acid-digestion-sedimentssludges-and-oils

[21] V. Kastratović, S. Krivokapić, M. Bigović, D. Đurović, N. Blagojević, J. Serb. Chem. Soc. 2014, 79(11), 14451460. https://doi.org/10.2298/JSC140409074K

[22] V. Kastratović, S. Krivokapić, D. Đurović, N. Blagojević, J. Serb. Chem. Soc. 2013, 78(8), 1241-1258. https://doi.org/10.2298/JSC121026153K

[23] E. Podlesakova, J. Nemecek, R. Vacha, Mobility and bioavailability of trace elements in soils. Trace Elements in Soil. Bioavailability, Flux, and Transfer, $1^{\text {st }}$ Edition (Eds.: I. K. Iskandar, M. B. Kirkham), CRC Press, Boca Raton, 2001 https://doi.org/10.1201/9781420032734 
[24] P. H. T. Beckett, Adv. Soil Sci. 1989, 9, 143-176. https://doi.org/10.1007/978-1-4612-3532-3_3

[25] M. Sharofova, S. Abdullaev, V. Maslov, Sh. Sagdieva, E. V. Shikh, M. Mirshahi, Environ. Monit. Assess. 2021, 193, 127. https://doi.org/10.1007/s10661-021-08909-2

[26] Element Concentration Cadaster in Ecosystems ECCE, (1994). Progres Report. Presented at the $25^{\text {th }}$ general Assembly of International Union of Biological Sciences (IUBS), Paris, France.

[27] R. Kastori, N. Petrović, I. Arsenijević-Maksimović, Heavy metals and plants. Heavy Metals in the Environment, Scientific Institute of Field and vegetable Crops, Novi Sad, Serbia, pp. 196-257, 1997.

[28] R. L. Chaney, Inorganic contaminants in the vadose zone, Springer, Berlin, Heidelberg, 1989, pp. 140-158. https://doi.org/10.1007/978-3-642-74451-8_10

[29] C. Radulescu, C. Stihi, I. V. Popescu, I. Ionita, I. D. Dulama, A. Chilian, O. R. Bancuta, E. D. Chelarescu, D. Let, Rom. Rep. Phys. 2013, 65(1), 246-260.

[30] N. K. Glavač, S. Djogo, S. Ražić, S. Kreft, M. Veber, Arh. Ind. Rada. Toksikol. 2017, 68(3), 236-244. https://doi.org/10.1515/aiht-2017-68-2990

[31] X. P. Wang, X. Q. Shan, S. Z. Zhang, B. Wen, Chemosphere, 2004, 55, 811-822.

https://doi.org/10.1016/j.chemosphere.2003.12.003

[32] S. Ražić, S. Đogo, Chemosphere, 2010, 78, 451-456. https://doi.org/10.1016/j.chemosphere.2009.10.028

[33] R. Musielińska, J. Kowol, J. Kwapuliński, R. Rochel, Arch. Environ. Prot. 2016, 42(2), 78-91. https://doi.org/10.1515/aep-2016-0022
[34] E. L. Nikolova, R. D. Valcheva, C. V. Angelov, Acta zool. bulg. 2018, 11, 163-167.

[35] G. Tewari, C. Pande, S. Shalini, C. Singh, J. Chem. Applied Biochem. 2015, 2(1), 109.

https://www.opensciencepublications.com/fulltext articles/JCAB-2394-3106-2-109.html

[36] S. S. Ranđelović, D. A. Kostić, A. R. Zarubica, S. S. Mitić, M. N. Mitić, Hem. Ind. 2013, 67(4), 585591.

https://doi.org/10.2298/HEMIND120703098R

[37] Y. Dogan, S. Baslar, I. Ugulu, Appl. Ecol. Environ. Res. 2014, 12(3), 627-636.

https://doi.org/10.15666/aeer/1203_627636

[38] R. D. Criste, A. E. Untea, M. Olteanu, D. Radutoiu, A. Lacatusu, L. Vladescu, Rev Chim-Bucharest, 2013, 64(3), 225-232.

https://www.revistadechimie.ro/Articles.asp?ID=3613

[39] M. M. Lasat, J. Hazard. Subst. Res. 2000, 2(1), 1-25. https://doi.org/10.4148/1090-7025.1015

[40] O. Ravera, J. Limnol. 2001, 60, 63-78. https://doi.org/10.4081/jlimnol.2001.s1.63

[41] D. Pavlova, I. Karadjova, I. Krasteva, Aust. J. Bot. 2015, 63(2), 152-158. https://doi.org/10.1071/BT14260

[42] D. Obratov-Petković, I. Bjedov, S. Belanović, Bulletin of the Faculty of Forestry, 2008, 98, 143-154. https://doi.org/10.2298/GSF08981430

[43] A. F. Santos Júnior, R. A. Matos, E. M. J. Andrade, W. N. L. dos Santos, H. I. F. Magalhães, F. N. Costa, M. G. A. Korn, J. Braz. Chem. Soc. 2017, 28(2), 376-384. https://doi.org/10.5935/0103-5053.20160187 